Article

\title{
Rural Destination Development Based on Olive Oil Tourism: The Impact of Residents' Community Attachment and Quality of Life on Their Support for Tourism Development
}

\author{
Ana María Campón-Cerro ${ }^{1, *}$ (D) , José Antonio Folgado-Fernández ${ }^{2}$ and \\ José Manuel Hernández-Mogollón ${ }^{1}$ \\ 1 Department of Business Management and Sociology, University of Extremadura, 10071 Cáceres, Spain; \\ jmherdez@unex.es \\ 2 Department of Financial Economics and Accounting, University of Extremadura, 10071 Cáceres, Spain; \\ jafolgado@unex.es \\ * Correspondence: amcampon@unex.es; Tel.: +34-927-257-480
}

Received: 24 July 2017; Accepted: 6 September 2017; Published: 13 September 2017

\begin{abstract}
Residents are an essential part of tourism destinations, which makes gaining a deeper understanding of residents' attitudes towards tourism development necessary because their favourable attitudes can contribute to destinations' success. This study sought to understand to what extent rural residents' perceptions of tourism development in their region affect their intention to support further tourism development. The present research also focused on the influence of the variables of community attachment and perceived quality of life on the relationship between residents' perceptions of and intentions to support this development. This study concentrated on the case of olive oil tourism development in the Sierra de Gata and Las Hurdes districts in Spain. To test the proposed model, the data were collected from a sample of 245 residents in this region. Partial least squares was used to assess the model's accuracy. The results highlight the importance of residents' perceptions and their community attachment and perceived quality of life to destination managers who plan and develop tourism projects.
\end{abstract}

Keywords: residents; attachment; quality of life; support for tourism development; rural tourism experiences; food tourism; olive oil tourism; destination marketing; sustainable destination management; partial least squares (PLS)

\section{Introduction}

In recent decades, rural areas have been going through a crisis, which has stimulated new initiatives to develop these areas through tourism activities. European countries are dealing with problems such as the decreasing of farm revenues, the changes in land values and the increasing of unemployment, which lead to the emigration of the work forces, generating a demographic imbalance in rural areas. Rural spaces need to adapt their economic structure to new farming technologies, information and communication technologies, and market conditions, as well as seek economic diversification, innovation and strengthen their competitiveness. Tourism has been considered a mechanism for rural development, taking into account that rural tourism is less costly and easy to implement than other strategies, because relatively little investment is required from local government and small businesses [1]. As a result, rural tourism now complements other sources of income in rural environments. However, this supporting role only becomes fully developed with the commercialisation of regional agrifood products. 
In addition, tourists to rural areas are increasingly giving value to authenticity, rural heritage and local content in their tourism experiences [2,3]. This has forced rural areas to seek out new alternatives that offer motivational and authentic experiences. In this context, olive oil tourism can complement farmers' income through tourism activities based on the ancient tradition of producing olive oil as an emerging tourism product. In addition, it is considered a way to create new companies and employment, and to preserve traditional techniques of olive oil production. According to Alonso and Northcote [4], for olive growers, olive oil tourism arises as an alternative to foster the marketing of olive oil and related value-added products, while for tourists it offers a new experience and an opportunity to know more about this key element in the Mediterranean diet.

Olive oil tourism is defined as a type of tourism 'whose motivation is related with everything that has to do with olive oil and the resources associated with the olive grove such us the terrain, water, landscape, culture or climate, among others' [5] (p. 137). Activities such as visiting olive groves, olive oil mills, museums and interpretation centres, tasting olive oil and derived dishes, and purchasing related products, among others, could be developed within this kind of tourism [5].

However, residents' support is necessary so that tourism products deeply rooted in local culture can function well. Residents are a part of the tourism product itself, and they can ensure destinations' success or lack of success in terms of tourists' level of satisfaction. Locals are the transmitters of their own culture and the customs and traditions particular to rural environments. Residents with negative attitudes towards tourism development may prevent tourists' enjoyment of authentic experiences that match the expectations of visitors seeking cultural experiences, including opportunities to learn and participate.

The economic benefits of tourism need to revert to the local population since inhabitants must be integrated and involved as protagonists in planning local development that facilitates the expansion of productive systems, thereby promoting sustainable development [6-8]. Given the importance and impact that residents have as actors in their own socioeconomic development, they need to be involved in policymaking that fosters rural development through tourism activities. Insofar as the tourism sector's success depends on local resources and services, destination managers have to be able to count on a friendly and hospitable population. Thus, these managers must understand the factors that influence residents' attitudes towards tourism development [9]. Research on residents and their support of tourism development has, therefore, become a systematic, active field of investigation in which social exchange theory has played a key role [10]. Social exchange theory posits 'that an individual's attitudes toward this industry, and subsequent level of support for its development, will be influenced by his or her evaluation of resulting outcomes in the community' [11] (p. 1061). Consequently, residents' support for tourism would depend on the positive or negative impacts they perceive of tourism development. The application of social exchange theory to residents' attitudes towards tourism has found support in the literature, however, some studies have not been conclusive [12].

Tourism in rural settings could be a good option for residents who want to preserve their rural heritage-landscapes, culture and lifestyles—and enhance or sustain local agricultural development [13]. In addition, it can be considered an opportunity to improve the community's wellbeing and their own [14]. However, tourism development does not always produce benefits. A wide diversity of stakeholders, facilities and resources participate in rural tourism. Therefore, in order to manage this complexity, a comprehensive framework to design a holistic model of tourism development is required. Such model has to take into account residents' perceptions as key drivers. Understanding the residents' perspective and shape them, if warranted, can promote the sustainable tourism planning success [15]. Residents are sensitive not only to the economic benefits of tourism development, but also to social and environmental effects. Subsequently, an important responsibility of developers is enhancing and communicating those positive impacts of tourism [16].

Research on residents' attitudes towards tourism is one of the most prolific areas of tourism research. A number of models have been proposed as an attempt to measure and predict residents' attitudes towards its development [12]. In the literature on tourism, studies are beginning to be published that examine the relationships between variables such as perceptions of tourism development, attitudes, 
community attachment or quality of life. This research is necessary because the benefits of tourism have changed over the years, moving away from adding economic value towards more abstract value [17].

The setting for the present study was the Sierra de Gata and las Hurdes (Cáceres, Extremadura) districts in Spain because these have been categorised as a protected designation of origin for Gata-Hurdes olive oil. This area is mainly agricultural and rural, with the same problems underlined by Gannon such as the decreasing of farm revenues and unemployment [1]. However, these districts are undergoing an economic transformation where the agrifood industry and tourism has an important role. As a result, they need to implement innovative strategies, in accordance with their place identity, to compete in global markets and develop tourism sustainably. With respect to their tourism development stage, they offered 137 tourist accommodations and 2630 accommodation vacancies in 2016, according to the General Directorate of Tourism of the Regional Government of Extremadura. Regarding the number of visitors, according to the figures provided by the Extremadura Tourism Observatory, 132,830 travellers visited the Sierra de Gata, Las Hurdes and Valle del Alagón districts, registering 253,171 overnights in 2015. However, the figures about the average stay (1.91 days) and the occupancy rate $(21.6 \%)$ need to be fostered, although a positive fact is that Las Hurdes and Sierra de Gata are in the fourth and fifth positions, respectively, in the ranking of tourism zones in Extremadura. Developing olive oil tourism it would be possible to enhance the tourism demand in this territory, but also promoting the selling of olive oil and related products.

The region corresponds to special concerns that justify the need for this type of research as these districts are located in a rural area seeking to overcome challenges in its socioeconomic development. These districts' local products face barriers when competing in a globalised market, and rural tourism could help improve the area's competitiveness. While these districts need to respond to changing demands, they also have significant value due to an identity based on a rich natural, cultural, gastronomic and ethnographic heritage. In addition, the area has tourism resources, and it is in the initial stages of developing an offer focused on olive oil tourism (e.g., museums, interpretation centres, visits to olive groves and mills, olive oil tasting and sampling, monuments and festivals).

Literature review points out that olive oil tourism has received little attention from the academics and practitioners $[4,5]$. Although a number of factors have been studied as predictors of the residents' attitudes towards tourism, the development of theoretical frameworks to interpret research findings has been limited [18]. Therefore, this study's objective was to understand to what extent rural residents' economic, social, environmental and physical benefits perceptions of tourism development in their region affect their intention to support further tourism development. The present research also examined the influence of the variables of community attachment and perceived quality of life on the relationship between residents' attitudes towards and general support for tourism development and, more specifically, for olive oil tourism projects. In essence, this study analysed the determinants of rural residents' support for tourism development based on endogenous resources.

\section{Theoretical Model and Research Hypotheses}

Research on residents' perceptions of the impacts of tourism development, as well as residents' support for this development, has generated a sizeable volume of literature, especially in more recent years (e.g., [19-23]). Many of these studies have analysed community attachment (e.g., [24,25]) and perceived quality of life (e.g., $[17,26,27])$ as factors to consider in the relationship between residents' perceptions of and support for tourism development. Although research on the impacts of tourism as seen by residents has become more important, regional administrators have not developed mechanisms for including residents in tourism planning processes [20]. This still occurs even though the integration of the local population in planning has been shown to be the most effective means to achieve sustainable tourism development [19]. In addition, understanding the implications of tourism development from residents' point of view helps to increase knowledge about the factors affecting the long-term, sustainable success of tourism destinations [17]. 
In recent decades, interest in tourism as a tool for regional development has greatly increased. Community leaders and economic development experts see it as an opportunity to increase employment, tax revenues and economic diversification [27]. However, when planning destinations, these leaders and experts must take into account that they need to promote sustainable tourism environments that benefit all stakeholders, namely, residents, visitors and local tourism businesses [28].

The literature reveals a lack of consensus regarding the variables that influence residents' support for tourism development [24]. However, understanding these antecedents is crucial to destination management because successful and sustainable development depends on the active support of local communities. Over the last decades, researchers have begun to analyse these factors, finding that community attachment is among the more important variables [29]. In addition, maintaining a high quality of life in the local community is vital to improving residents' attitudes towards tourism development as a source of socioeconomic benefits for the surrounding region [28].

In terms of applying this line of research to rural environments, Abdollahzadeh and Sharifzadeh [19] observe that little is known about residents' perceptions of tourism in rural settings. Thus, a better understanding of this phenomenon is fundamental to the development and implementation of management strategies for long-term sustainable tourism that takes into account the local population's needs and the best use of resources. The cited authors found that tourism creates jobs and opportunities to generate income in rural settings, improves services and well-being, develops a market for agricultural products and increases the demand for local products. In rural contexts, the implementation of tourism development based on endogenous regional resources has become important, as in the case of olive oil in some regions of Iberian Peninsula and Mediterranean countries.

The concept of place attachment has become a significant topic in recent years in research on tourism marketing [30]. Attachment includes relationships between people and their surroundings, which can be reflected in positive, negative or mixed feelings. In this way, it can play a key role in influencing residents' perceptions of and attitudes towards tourism development in their community $[25,31]$.

The variable of attachment as a predictor of the perceived costs and benefits of tourism development remains a topic of debate in the literature [24]. Researchers have reported contradictory findings on the influence of community attachment on residents' perceptions of tourism's impacts and the resulting levels of support for tourism development [29]. This reveals a pressing need to conduct more studies on these relationships.

Gursoy and Rutherfort [29] confirmed the direct positive impact of community attachment on perceptions of social and economic benefits, which suggests that people who are strongly attached to their community are more inclined to recognise the positive impacts of tourism. Lee's [24] study also showed a link between attachment and perceived benefits of tourism development, although the data did not confirm a relationship between attachment and perceived costs, which is in line with Gursoy and Kendall's [32] results. Gursoy et al. [9], in turn, could not find support for the relationship between attachment and the costs and benefits of tourism activities in relation to support for tourism development. Given these variations in results, further research clearly needs to be conducted on the above relationships, so the following hypothesis was proposed for the present study:

Hypothesis 1 (H1). Rural residents' attachment to their region positively affects their positive perceptions of tourism development in their region.

Nicholas et al. [25] analysed residents' support for their community's classification as 'World Heritage' and the resulting sustainable tourism development. The cited authors confirmed that attachment positively influences support behaviours. Based on these results, the second hypothesis of the present research was developed as follows:

Hypothesis 2 (H2). Rural residents' attachment to their region positively affects their intention to support tourism development in their region. 
An ample range of studies have analysed tourism's impacts as a component of tourism development [27]. Stydilis et al. [23] found proof that perceptions of tourism's economic, sociocultural and environmental impacts influence support for tourism development. Similarly, Nunkoo and Rakimssoon [22], Nunkoo and Gursoy [21] and Ko and Stewart [33] confirmed the relationship between residents' attitudes and support for tourism development. However, the cited authors' findings differentiate between residents' attitudes towards the positive and negative impacts of tourism. Other studies also have been interested in this relationship [9,29,34,35]. Given this previous research, the following hypothesis was proposed for the present study:

Hypothesis 3 (H3). Rural residents' positive perceptions of tourism development positively affect their intention to support tourism development in their region.

While the economic impact of tourism has been extensively analysed in previous research, few studies have focused on more abstract issues such as residents' quality of life and well-being [17]. When planning a new destination or revitalising an existing one, destination managers need to avoid or mitigate negative factors that can affect residents' quality of life, especially in high season when tourist flows can overwhelm the carrying capacity of infrastructure and local resources [28]. In the present study, quality of life was defined as 'an aggregation of residents' perceptions of economic, social and environmental conditions, as well as comprehensive perceptions of well-being in the host community, embracing residents' subjective well-being and objective well-being' [28] (p. 199).

Some previous studies have examined the relationship between the costs and benefits of tourism and residents' quality of life in tourism destinations [28]. However, few researchers have explicitly analysed the relationship between residents' perceptions of tourism's impacts and their perceived quality of life [10]. In contrast, the connection between tourism development and residents' improved quality of life has received more attention in recent years [17].

A series of empirical studies have shown that residents' support of tourism has a positive relationship with their perceptions of positive impacts but an inverse relationship with perceptions of negative impacts. Positive economic, sociocultural and environmental impacts improve residents' quality of life [10], but residents' attitudes towards tourism and their level of support for tourism development and their perceived quality of life can vary depending on their evaluation of the cost-benefit ratio [17]. Jeon et al. [28] analysed the impacts of tourism and their relationship with residents' quality of life. The cited authors found that economic benefits and environmental sustainability have a positive effect on quality of life, while social costs have an inverse effect on quality of life. These relationships also have been examined in other studies (e.g., [26,27]). Based on these findings, the fourth hypothesis of the present study was formulated as:

Hypothesis 4 (H4). Rural residents' positive perceptions of tourism development in their region positively affects their perceived quality of life.

While most research has treated residents' satisfaction with their quality of life as a dependent variable influenced by tourism's impacts, only recent studies have considered quality of life an antecedent of residents' support of tourism development. In this way, if tourism's impacts improve their quality of life, residents are more likely to support further tourism development [10].

The literature shows a consensus that quality of life influences residents' attitudes towards future tourism development in their community. However, while this relationship has been mentioned in some formal studies, it has not yet been empirically confirmed [36]. Running contrary to general opinion, Nunkoo and So's [10] research could not find proof for the relationship between residents' satisfaction with their quality of life and their support of tourism. Thus, a fuller understanding of this relationship is required, as proposed in the present study's final hypothesis: 
Hypothesis 5 (H5). Rural residents' perceived quality of life positively affects their support of tourism development in their region.

Figure 1 shows the theoretical model.

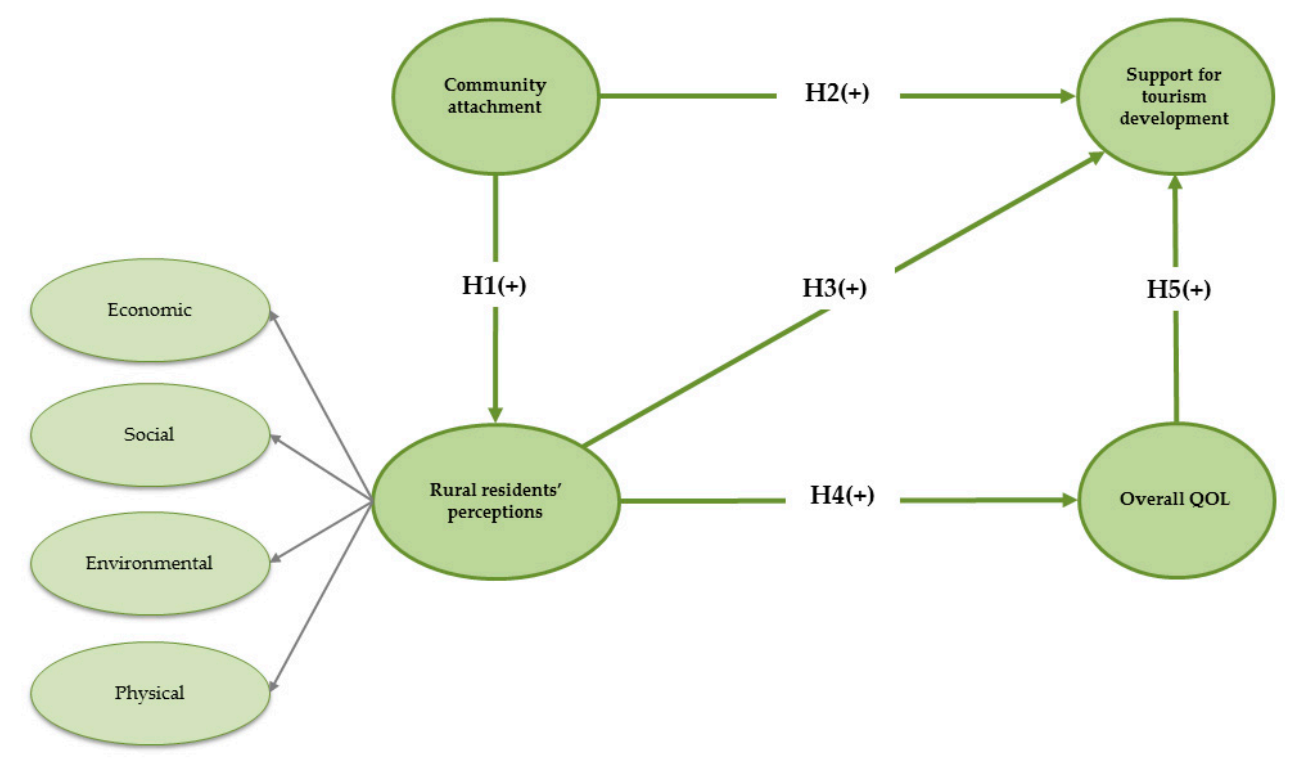

Figure 1. Theoretical model.

\section{Materials and Methods}

To test the proposed model, the present study used previously validated scales found in the literature (see Table 1). The following considerations were taken into account when choosing two of the scales used. The scale developed by Abdollahzadeh and Sharifzadeh [19] was selected as the basic scale because it focused especially on rural residents' perceptions towards tourism development. However, the items related to negative perceptions of tourism development were eliminated to avoid bias in the interpretation of the above hypotheses and test results. The items assessing the physical dimension were adapted for the present study's context. The scale measuring support for tourism development came from Woo et al.'s [17] research, which included an item related to tourism development in rural areas based on endogenous products such as olive oil. To ensure the suitability of the scales used, a pretest was conducted with six scholars involved in research in the field of marketing and tourism management from the University of Extremadura, which helped to refine the scales further before they were used. The final questionnaire was composed by three parts. The first one deals with the opinion that residents have about the tourism development of their district, the appealing of the tourism attractions and the possibilities of the development of olive oil tourism. After that, the variables of the model are presented in five-point Likert scales. Finally, some questions about the residents' demographic profile are exposed.

A quantitative methodology was chosen for this study, which was based on a direct personal survey conducted with an online questionnaire to facilitate the introduction and tabulation of responses in a database using Google Forms. The geographical scope of the study encompassed the Sierra de Gata and Las Hurdes (Cáceres) districts of Spain. The fieldwork was carried out in March 2016, resulting in a non-probability convenience sample of 245 residents.

IBM SPSS Statistics Version 21.0 was used to carry out the descriptive analysis of the data. The proposed model was analysed through structural equation modelling using partial least squares (PLS). This method was selected because it is especially appropriate for exploratory studies involving predictive models with a higher level of complexity due to second-order constructs [37], as was the case in the present research. The following section presents the results of the analyses. 
Table 1. Scales used.

\begin{tabular}{|c|c|c|}
\hline Author/s & Variable/dimension & Indicators \\
\hline \multirow{19}{*}{$\begin{array}{l}\text { Abdollahzadeh } \\
\text { and Sharifzadeh } \\
\quad[19]\end{array}$} & \multirow{7}{*}{$\begin{array}{l}\text { Rural residents' } \\
\text { perceptions (economic } \\
\text { benefits) (RRPE) }\end{array}$} & (RRPE1) Tourism favours the sale of farm products. \\
\hline & & (RRPE2) Tourism creates many jobs for locals. \\
\hline & & (RRPE3) Tourism increases local incomes. \\
\hline & & (RRPE4) Tourism increases the demand for local products. \\
\hline & & (RRPE5) Tourism creates new business investment opportunities. \\
\hline & & (RRPE6) Tourism diversifies rural economies. \\
\hline & & (RRPE7) Tourism ensures local businesses' long-term profitability. \\
\hline & \multirow{6}{*}{$\begin{array}{l}\text { Rural residents' } \\
\text { perceptions (social } \\
\text { benefits) (RRPS) }\end{array}$} & (RRPS1) Tourism improves local standards of living. \\
\hline & & $\begin{array}{l}\text { (RRPS2) Tourism increases awareness of the importance of tourism through } \\
\text { interactions between residents and visitors. }\end{array}$ \\
\hline & & (RRPS3) Tourism enhances respect for local culture and customs. \\
\hline & & (RRPS4) Tourism enhances residents' participation in local activities. \\
\hline & & (RRPS5) Tourism develops a sense of belonging to the surrounding region. \\
\hline & & (RRPS6) Tourism creates new learning opportunities for residents. \\
\hline & \multirow{3}{*}{$\begin{array}{c}\text { Rural residents' } \\
\text { perceptions } \\
\text { (environmental benefits) } \\
\text { (RRPN) }\end{array}$} & (RRPN1) Tourism fosters environmental conservation. \\
\hline & & (RRPN2) Tourism provides more recreational opportunities for locals. \\
\hline & & (RRPN3) Tourism favours declarations of protected natural areas. \\
\hline & \multirow{3}{*}{$\begin{array}{l}\text { Rural residents' } \\
\text { perceptions (physical } \\
\text { benefits) (RRPP) }\end{array}$} & (RRPP1) Tourism increases the value of property owned by locals. \\
\hline & & $\begin{array}{l}\text { (RRPP2) Tourism increases investment in tourism infrastructure } \\
\text { (e.g., hotels, restaurants, local products and souvenirs shops, campsites and } \\
\text { parking areas). }\end{array}$ \\
\hline & & $\begin{array}{l}\text { (RRPP3) Tourism increases investment in rural infrastructure (e.g., roads, } \\
\text { sanitation, supply lines and health centres). }\end{array}$ \\
\hline \multirow{3}{*}{ Woo et al. [17] } & \multirow{3}{*}{$\begin{array}{l}\text { Overall quality of life } \\
\qquad \text { (QOL) }\end{array}$} & (QOL1) The conditions of my life are excellent. \\
\hline & & (QOL2) I have gotten the important things I want in life. \\
\hline & & (QOL3) In general, I am satisfied with my life. \\
\hline \multirow{4}{*}{$\begin{array}{l}\text { Woo et al. [17] } \\
\text { and a proposal }\end{array}$} & \multirow{4}{*}{$\begin{array}{l}\text { Support for tourism } \\
\text { development (STD) }\end{array}$} & $\begin{array}{l}\text { (STD1) I perceive the impacts of tourism development in my community } \\
\text { as positive. }\end{array}$ \\
\hline & & (STD2) I would support further tourism development in my community. \\
\hline & & $\begin{array}{l}\text { (STD3) I would support further tourism development based on olive oil } \\
\text { production in my community (new). }\end{array}$ \\
\hline & & $\begin{array}{l}\text { (STD4) Further tourism development would positively affect my } \\
\text { community's quality of life. }\end{array}$ \\
\hline \multirow{10}{*}{ Lee [24] } & \multirow{10}{*}{$\begin{array}{l}\text { Community attachment } \\
\text { (CAT) }\end{array}$} & (CAT1) The infrastructure, facilities and services of my region are the best. \\
\hline & & (CAT2) I prefer living in this community over other places. \\
\hline & & (CAT3) I enjoy living in this community more than in other places. \\
\hline & & (CAT4) I identify personally with the life of this community. \\
\hline & & (CAT5) I feel that this community is a part of me. \\
\hline & & (CAT6) Living in this community says a lot about me. \\
\hline & & (CAT7) Living in this community means a lot to me. \\
\hline & & (CAT8) I am very attached to this community. \\
\hline & & (CAT9) I have a strong sense of belonging to this community. \\
\hline & & (CAT10) My friends and relatives prefer this community over other places. \\
\hline
\end{tabular}

\section{Results}

\subsection{Analysis of Sample Profile}

The sample was $50.6 \%$ male and $49.4 \%$ female. The largest age group was participants between 46 and 55 years old (37.6\%), followed by those over 55 years old (27.3\%) and between 36 and 45 years 
old (17.1\%). The most common education level was secondary school (44.1\%), followed by primary school (35.5\%).

The residents surveyed think that the Sierra de Gata and Las Hurdes region has a medium-high level of tourism development (an average of 3.64 out of 5) and that the tourists who visit the area show considerable interest in olive oil tourism (4.04). In addition, these residents believe that olive oil tourism has a high potential for success in their region (4.23). Based on these data, the geographical context in question was considered appropriate, given the present study's objectives.

\subsection{Causal Analysis of Model: Preliminary Remarks}

Using PLS to evaluate the proposed model entailed first analysing the measurement model and, only then, the structural model. However, since the model included the variable of rural residents' perceptions, which has four dimensions (i.e., economic, social, environmental and physical benefits), it was necessary to apply the two-step approach suggested by Ciavolino and Nitti [38]. The analyses also followed the steps outlined by Wright et al. [39]. Based on MacKenzie et al.'s [40] recommendations, all the model's indicators were understood as being reflective, so the measurement model was evaluated according to this specification, following Hair et al.'s [37] suggestions.

\subsection{Analysis of Measurement Model: First Step}

The first step involved analysing the individual reliability of the indicators, internal consistency of the construct, convergent validity and discriminant validity based on Hair et al.'s [37] guidelines for models with reflective indicators. Regarding the individual reliability of the indicators, the results revealed items whose loadings $(\lambda)$ did not reach the critical threshold to be accepted in the model (i.e., equal to or greater than $0.707[37,41]$ ), although loadings of 0.50 or 0.60 are acceptable when the scales are being developed or applied to different contexts [41]. The indicators in question were RRPE7 $(\mathrm{RRPE}=$ rural residents' perceptions (economic benefits) $)($ mean $=3.04$; standard deviation $[\mathrm{SD}]=1.023$; $\lambda=0.3661)$ and CAT1 (CAT $=$ community attachment) $($ mean $=2.47 ; \mathrm{SD}=0.861 ; \lambda=0.3781)$.

After these items were eliminated, the model's remaining items showed individual reliability. The internal consistency of the constructs was also verified, showing a composite reliability higher than the required thresholds (i.e., between 0.60 and 0.70 suggested for exploratory studies and between 0.70 and 0.90 for research in later stages [42]). In addition, convergent validity was evaluated using average variance extracted (AVE), which needed to be above 0.5 [37] (see Table 2). 
Table 2. Measurement model assessment (first step).

\begin{tabular}{|c|c|c|c|c|c|c|}
\hline Variables, Dimensions and Indicators & Mean & $\begin{array}{c}\text { Standard } \\
\text { Deviation }\end{array}$ & Loading & $t$-Test ${ }^{\dagger}$ & $\begin{array}{l}\text { Composite } \\
\text { Reliability }\end{array}$ & $\begin{array}{c}\text { Average } \\
\text { Variance } \\
\text { Extracted } \\
\text { (AVE) }\end{array}$ \\
\hline Rural residents' perceptions (economic benefits) & - & - & - & - & 0.87 & 0.5279 \\
\hline RRPE1 & 4.15 & 0.642 & $0.6899^{* * *}$ & 9.0787 & - & - \\
\hline RRPE2 & 4.00 & 0.601 & $0.7751^{* * *}$ & 14.271 & - & - \\
\hline RRPE3 & 4.15 & 0.715 & $0.7059^{* * *}$ & 13.6437 & - & - \\
\hline RRPE4 & 4.09 & 0.711 & $0.7679^{* * *}$ & 22.066 & - & - \\
\hline RRPE5 & 4.07 & 0.655 & $0.7435^{* * *}$ & 15.9936 & - & - \\
\hline RRPE6 & 3.88 & 0.736 & $0.6707^{* * *}$ & 14.0865 & - & - \\
\hline Rural residents' perceptions (social benefits) & - & - & - & - & 0.8741 & 0.537 \\
\hline RRPS1 & 3.70 & 0.773 & $0.7135^{* * *}$ & 12.846 & - & - \\
\hline RRPS2 & 3.75 & 0.659 & $0.7716^{* * *}$ & 15.5916 & - & - \\
\hline RRPS3 & 3.44 & 0.831 & $0.7379^{* * *}$ & 17.5979 & - & - \\
\hline RRPS4 & 3.50 & 0.803 & $0.7496^{* * *}$ & 19.1042 & - & - \\
\hline RRPS5 & 3.48 & 0.828 & $0.7622^{* * *}$ & 20.2547 & - & - \\
\hline RRPS6 & 3.59 & 0.803 & $0.6562^{* * *}$ & 14.9231 & - & - \\
\hline Rural residents' perceptions (environmental benefits) & - & - & - & - & 0.7439 & 0.5022 \\
\hline RRPN1 & 3.38 & 1.043 & $0.5311^{* * *}$ & 4.2919 & & \\
\hline RRPN2 & 3.84 & 0.743 & $0.8778^{* * *}$ & 21.4526 & - & - \\
\hline RRPN3 & 3.51 & 0.952 & $0.6739^{* * *}$ & 8.7888 & & \\
\hline Rural residents' perceptions (physical benefits) & - & - & - & - & 0.7827 & 0.5516 \\
\hline RRPP1 & 3.91 & 0.711 & $0.792 * * *$ & 14.4057 & - & - \\
\hline RRPP2 & 3.78 & 0.762 & $0.8355^{* * *}$ & 17.7643 & - & - \\
\hline RRPP3 & 3.18 & 1.102 & $0.5738^{* * *}$ & 7.0567 & - & - \\
\hline Community attachment & - & - & - & - & 0.9172 & 0.5524 \\
\hline CAT2 & 3.93 & 0.680 & $0.7261^{* * *}$ & 13.3553 & - & - \\
\hline CAT3 & 4.04 & 0.673 & $0.7439^{* * *}$ & 14.5896 & - & - \\
\hline CAT4 & 4.13 & 0.755 & $0.7153^{* * *}$ & 13.3823 & - & - \\
\hline CAT5 & 4.22 & 0.743 & $0.7261^{* * *}$ & 13.0046 & - & - \\
\hline CAT6 & 4.11 & 0.776 & $0.7656^{* * *}$ & 18.4807 & - & - \\
\hline CAT7 & 4.14 & 0.745 & $0.7815^{* * *}$ & 19.9089 & - & - \\
\hline CAT8 & 4.16 & 0.779 & $0.7881^{* * *}$ & 22.6497 & - & - \\
\hline CAT9 & 4.02 & 0.804 & $0.7826^{* * *}$ & 21.328 & - & - \\
\hline CAT10 & 3.92 & 0.737 & $0.6491^{* * *}$ & 9.4938 & - & - \\
\hline Overall quality of life & - & - & - & - & 0.8995 & 0.7491 \\
\hline QOL1 & 3.71 & 0.791 & $0.8448^{* * *}$ & 33.4654 & - & - \\
\hline QOOL2 & 3.55 & 0.801 & $0.8939^{* * *}$ & 59.2901 & - & - \\
\hline QOL3 & 3.65 & 0.819 & $0.8571^{* * *}$ & 48.4849 & - & - \\
\hline Support for tourism development & - & - & - & - & 0.8744 & 0.6359 \\
\hline STD1 & 3.92 & 0.740 & $0.7817^{* * *}$ & 26.8698 & - & - \\
\hline STD2 & 4.19 & 0.688 & $0.8645^{* * *}$ & 40.1102 & - & - \\
\hline STD3 & 4.29 & 0.721 & $0.8085^{* * *}$ & 21.5057 & - & - \\
\hline STD4 & 4.38 & 0.833 & $0.7291 * * *$ & 13.4159 & - & - \\
\hline
\end{tabular}

Finally, discriminant validity was analysed to ensure that the correlations between the constructs are lower than the square root of the AVE [41]. The latter values appear along the diagonal in bold, confirming discriminant validity (see Table 3). Based on this assessment of the measurement model, it was considered valid and reliable, so the second step in the analyses could be done. 
Table 3. Discriminant validity analysis (first step).

\begin{tabular}{|c|c|c|c|c|c|c|c|}
\hline & $\begin{array}{l}\text { Community } \\
\text { Attachment }\end{array}$ & $\begin{array}{c}\text { Support for } \\
\text { Tourism } \\
\text { Development }\end{array}$ & $\begin{array}{l}\text { Overall } \\
\text { Quality } \\
\text { of Life }\end{array}$ & $\begin{array}{l}\text { Economic } \\
\text { Benefits }\end{array}$ & $\begin{array}{l}\text { Physical } \\
\text { Benefits }\end{array}$ & $\begin{array}{c}\text { Environmental } \\
\text { Benefits }\end{array}$ & $\begin{array}{c}\text { Social } \\
\text { Benefits }\end{array}$ \\
\hline $\begin{array}{l}\text { Community } \\
\text { attachment }\end{array}$ & 0.7131 & 0 & 0 & 0 & 0 & 0 & 0 \\
\hline $\begin{array}{l}\text { Support for } \\
\text { tourism } \\
\text { development }\end{array}$ & 0.4788 & 0.7974 & 0 & 0 & 0 & 0 & 0 \\
\hline $\begin{array}{l}\text { Overall quality } \\
\text { of life }\end{array}$ & 0.3697 & 0.5641 & 0.8655 & 0 & 0 & 0 & 0 \\
\hline $\begin{array}{c}\text { Economic } \\
\text { benefits }\end{array}$ & 0.4898 & 0.5035 & 0.3799 & 0.6840 & 0 & 0 & 0 \\
\hline Physical benefits & 0.4265 & 0.4091 & 0.2502 & 0.4693 & 0.7428 & 0 & 0 \\
\hline $\begin{array}{c}\text { Environmental } \\
\text { benefits }\end{array}$ & 0.3933 & 0.3467 & 0.2377 & 0.4918 & 0.3996 & 0.7090 & 0 \\
\hline Social benefits & 0.3095 & 0.4472 & 0.2437 & 0.5795 & 0.3974 & 0.3901 & 0.7329 \\
\hline
\end{tabular}

\subsection{Analysis of the Measurement Model: Second Step}

After the first step of the evaluation of the initial measurement model was complete, the scores were used to develop the model of the second-order construct 'rural residents' perceptions' by incorporating the aggregate scores calculated using PLS. This process resulted in an indicator for each dimension. The new nomological structure of the model had to be retested. We assumed that the new scores incorporated were reflective indicators based on MacKenzie et al.'s [40] suggestions. Table 4 shows that the scores for the items' individual reliability, as well as their composite reliability and convergent validity, fell above the critical thresholds.

Table 4. Measurement model assessment (second step).

\begin{tabular}{lcccc}
\hline Variables, Dimensions and Indicators & Loading & $\boldsymbol{t}_{\text {-Test }}{ }^{+}$ & Composite Reliability & AVE \\
\hline Rural residents' perceptions & - & - & 0.8523 & 0.5918 \\
ECON (Economic benefits) & $0.8551^{* * *}$ & 26.45 & - & - \\
SOCI (Social benefits) & $0.7599^{* * *}$ & 17.2528 & - & - \\
ENVI (Environmental benefits) & $0.721^{* * *}$ & 13.0037 & - & - \\
PHYS (Physical benefits) & $0.7341^{* * *}$ & 12.9858 & - & - \\
Community attachment & - & - & 0.9172 & - \\
CAT2 & $0.7251^{* * *}$ & 12.7208 & - & - \\
CAT3 & $0.7431^{* * *}$ & 14.0547 & - & - \\
CAT4 & $0.717^{* * *}$ & 13.7413 & - & - \\
CAT5 & $0.7258^{* * *}$ & 12.6907 & - & - \\
CAT6 & $0.7642^{* * *}$ & 18.2352 & - & - \\
CAT7 & $0.7806^{* * *}$ & 19.9116 & - & - \\
CAT8 & $0.7886^{* * *}$ & 22.977 & - & - \\
CAT9 & $0.7824^{* * *}$ & 21.4049 & - & - \\
CAT10 & $0.6517^{* * *}$ & 9.5316 & - & 0.7491 \\
Overall quality of life & - & - & - \\
QOL1 & $0.8444^{* * *}$ & 33.7417 & - & - \\
QOL2 & $0.895^{* * *}$ & 59.6337 & - & - \\
QOL3 & $0.8563^{* * *}$ & 47.8787 & - & - \\
Support for tourism development & - & - & - & - \\
STD1 & $0.782^{* * *}$ & 26.8449 & 0.8744 & - \\
STD2 & $0.8631^{* * *}$ & 38.0854 & - & - \\
STD3 & $0.8071^{* * *}$ & 22.9122 & - & - \\
STD4 & $0.7319^{* * *}$ & 14.1805 & - & - \\
\hline
\end{tabular}

${ }^{\dagger}$ Notes: Critical $t$-values: ${ }^{*} p<0.05 ;{ }^{* *} p<0.01 ; * * * p<0.001 ;{ }^{\text {ns }}$ not significant (based on $t(4999)$, one-tailed test); $t(0.05 ; 4999)=1.645 ; t(0.01 ; 4999)=2.327 ; t(0.001 ; 4999)=3.092$. 
As can be seen in Table 5, the model was shown to have discriminant validity after the second step was complete. Based on the results of the two-step approach, the final measurement model was considered reliable and valid, so the structural model could be analysed next.

Table 5. Discriminant validity analysis (second step).

\begin{tabular}{ccccc}
\hline & $\begin{array}{c}\text { Community } \\
\text { Attachment }\end{array}$ & $\begin{array}{c}\text { Support for Tourism } \\
\text { Development }\end{array}$ & $\begin{array}{c}\text { Overall Quality of } \\
\text { Life }\end{array}$ & $\begin{array}{c}\text { Rural Residents' } \\
\text { Perceptions }\end{array}$ \\
\hline $\begin{array}{c}\text { Community } \\
\text { attachment }\end{array}$ & $\mathbf{0 . 7 4 3 2}$ & 0 & 0 & 0 \\
\hline $\begin{array}{c}\text { Support for tourism } \\
\text { development }\end{array}$ & 0.4793 & $\mathbf{0 . 7 9 7 4}$ & 0 & 0 \\
\hline Overall quality of life & 0.3698 & 0.564 & $\mathbf{0 . 8 6 5 5}$ & 0 \\
\hline $\begin{array}{c}\text { Rural residents' } \\
\text { perceptions }\end{array}$ & 0.5322 & 0.5597 & 0.369 & $\mathbf{0 . 7 6 9 3}$ \\
\hline
\end{tabular}

Notes: The square root of the AVE appears along the diagonal in bold.

\subsection{Evaluation of Structural Model}

To evaluate the structural model, the R-squared for each dependent construct was analysed, as well as the significance of the paths, using bootstrapping-based on Hair et al.'s [37] guidelines. According to Falk and Miller [43], it is also necessary to specify how much the predictor variables contribute to the explained variance of the endogenous variables.

According to the results shown in Table 6, the model's latent endogenous variables have a weak-to-moderate explanatory power. The model can explain $28.3 \%$ of the residents' perceptions through the effect of attachment, $13.6 \%$ through the impact of rural residents' perceptions, and $47.9 \%$ of support for tourism development. The latter is influenced primarily by quality of life (21.5\%), followed closely by rural residents' perceptions $(18.7 \%)$ - with a lesser impact associated with attachment $(7.7 \%)$.

Table 6. Effects on endogenous variables.

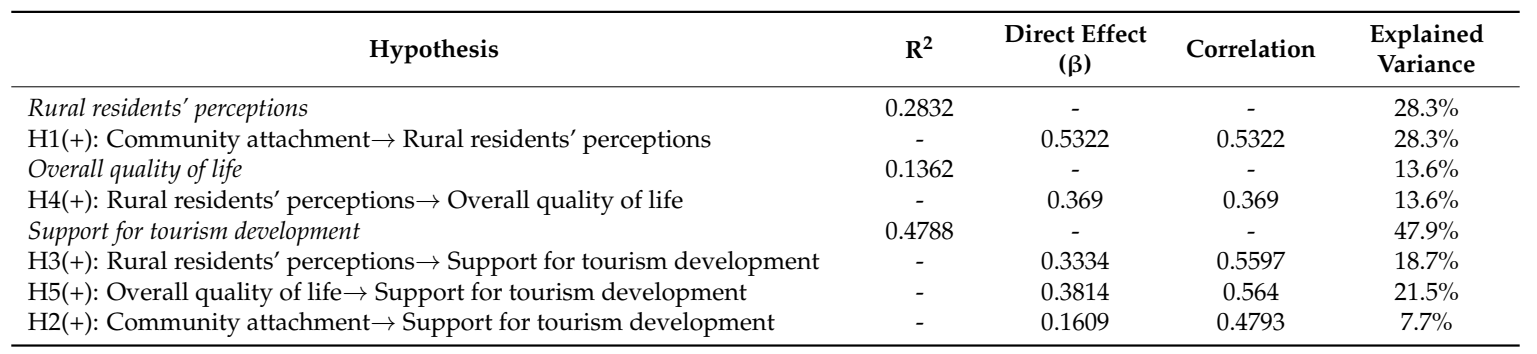

Table 7 presents the results for the structural model. The analysis of the significance of paths revealed that the research hypotheses received empirical support from the results, thereby validating the proposed model. The graphical summary of the evaluation of the structural model can be seen in Figure 2 below. 
Table 7. Structural model results.

\begin{tabular}{|c|c|c|c|}
\hline Hypothesis & $\begin{array}{c}\text { Path } \\
\text { Coefficient }(\beta)\end{array}$ & $\begin{array}{c}t \text {-Value } \\
\text { (Bootstrap) }\end{array}$ & Support \\
\hline $\mathrm{H} 1(+)$ : Community attachment $\rightarrow$ Rural residents' perceptions & $0.5322 * * *$ & 4.6149 & Yes \\
\hline $\mathrm{H} 2(+)$ : Community attachment $\rightarrow$ Support for tourism development & $0.1609 *$ & 2.3041 & Yes \\
\hline $\mathrm{H} 3(+)$ : Rural residents' perceptions $\rightarrow$ Support for tourism development & $0.3334^{* * *}$ & 4.6218 & Yes \\
\hline $\mathrm{H} 4(+)$ : Rural residents' perceptions $\rightarrow$ Overall quality of life & $0.369 * * *$ & 4.3018 & Yes \\
\hline $\mathrm{H} 5(+)$ : Overall quality of life $\rightarrow$ Support for tourism development & $0.3814^{* * *}$ & 7.7585 & Yes \\
\hline
\end{tabular}

${ }^{\dagger}$ Notes: Critical $t$-values: ${ }^{*} p<0.05 ;{ }^{* *} p<0.01 ;{ }^{* * *} p<0.001 ;{ }^{\text {ns }}$ not significant (based on $t(4999)$, one-tailed test); $t(0.05 ; 4999)=1.645 ; t(0.01 ; 4999)=2.327 ; t(0.001 ; 4999)=3.092$.

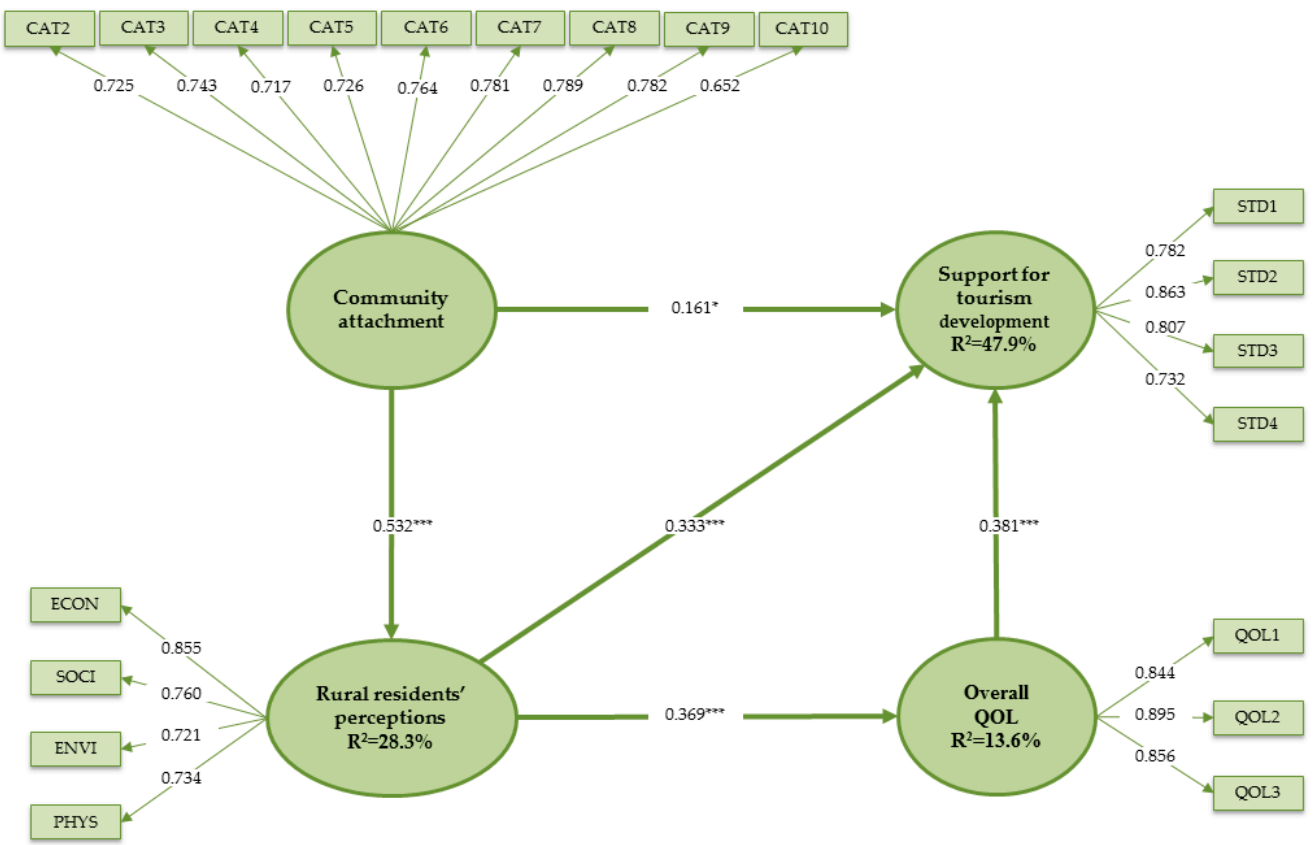

Figure 2. Graphical results of structural model assessment. Notes: Critical $t$-values: ${ }^{*} p<0.05$; ${ }^{* *} p<0.01 ;{ }^{* * *} p<0.001 ;$ ns not significant (based on $t(4999)$, one-tailed test); $t(0.05 ; 4999)=1.645$; $t(0.01 ; 4999)=2.327 ; t(0.001 ; 4999)=3.092$.

\section{Discussion}

The results of the evaluation of the proposed model are in line with the findings of previous studies. The present findings for the relationship between community attachment and perceptions of tourism's impacts on rural environments (i.e., H1) agree with Gursoy and Rutherfort [29], Lee [24] and Gursoy and Kendall's [32] findings. Accordingly, the positive impact of community attachment on residents' perceptions suggests that residents who are strongly attached to their community are more conscious of the benefits of tourism development [29]. Regarding H2, the present results are in line with those of Nicholas et al. [25], confirming that community attachment influences support for tourism development behaviours. According to these authors, this is not a surprising result, because the more attached residents are to their community, the more supportive they will be of developing tourism in a sustainable way. Thus destination managers should adopt sustainable practices when developing tourism policies.

The relationship found between perceptions of tourism's economic, social, physical and environmental impacts and these perceptions' relationship with support for tourism development in rural settings (i.e., H3) is in line with Stydilis et al.'s [23] results. The present findings also agree with Nunkoo and Rakimssoon [22], Nunkoo and Gursoy [21] and Ko and Stewart's [33] results, although, in the cited studies, the researchers differentiated between positive and negative impacts and their relationship with support for tourism development. 
In terms of H4, the current findings agree with Jeon et al.'s [28] results for cultural tourism destinations. Therefore tourism in rural settings, when developed based on an endogenous product such as olive oil and its heritage, has positive economic, social, environmental and physical benefits that are going to enhance residents' quality of life. The results for $\mathrm{H} 5$ confirm the general consensus in the literature about the influence of quality of life on residents' attitudes towards tourism development, in contrast to Nunkoo and So's [10] results, that could not prove the relationship between residents' satisfaction with their quality of life and the support of tourism.

The main results of this model reveal that rural residents' perceptions, community attachment and overall quality of life are significant predictors of residents' support for tourism development $(47.9 \%)$, being the most important antecedent quality of life (18.7\%), followed by rural residents' perceptions $(18.7 \%)$ and community attachment $(7.7 \%)$. These results are in accordance with the results proposed by the social exchange theory, where attitudes towards tourism development and its support are influenced by the outcomes perceived by the community. In this model, the perception of quality of life plays an important role as a positive outcome and as a factor that fosters their support for tourism development in rural settings.

It is also important to underline that the main component of rural residents' perceptions in the model tested is economic benefits. In this regard the majority of studies have demonstrated that residents who are more dependent on the tourism activity are likely to have a more positive perception of tourism than other residents [12], a finding also in accordance with Chuang's [13] results.

The present findings emphasise the importance of the variables analysed as key elements to consider when tourism managers develop plans and seek to ensure their destinations' success. In the districts under study, this can be done by promoting olive oil tourism in rural areas, thus basing further tourism development on an authentic regional product.

\section{Conclusions}

This study sought to highlight the importance of residents as key players in tourism development in rural areas, especially in terms of local heritage. This involves natural, cultural and gastronomic features, as is the particular case of olive oil tourism on which the present research focused.

The results provide empirical support for the causal relationships proposed between perceptions of tourism development, community attachment, quality of life and support for further tourism development. This means that the research hypotheses are valid and the findings agree with previous research. After validating the proposed theoretical model through analyses of the data collected, a direct relationship can be said to exist between residents' community attachment and perceptions of tourism's impacts in the context of tourism development in rural environments. In addition, rural residents are more likely to decide to support tourism development when they more clearly perceive improvements in their quality of life. This is, more specifically, applicable to new tourism initiatives such as olive oil tourism. The results further confirm that residents play a fundamental role in planning for tourism development, showing this to be applicable in the context of new rural tourism products such as olive oil tourism.

The main theoretical contribution of this work is the key role that residents perform in tourism development in rural settings, even more when a type of tourism based on the local culture, lifestyles and landscapes is developed, as olive oil tourism is. The contribution of this study is twofold. On the one hand, this study contributes to expand the literature about olive oil tourism. On the other hand, this study advances the knowledge of the predictors of support for tourism development, specifically applied in rural settings with a great rural heritage.

In addition, destination managers need to understand that tourism development must take into consideration residents' perceptions and attitudes, as well as their community attachment and development projects' impacts on their quality of life. This information needs to be gathered before managers invest the scarce resources available in rural contexts to ensure development projects' success-translating this information into effective communication strategies [29]. Destination 
managers can use internal marketing to inform residents of the benefits of tourism. Individuals with a strong community attachment also can become partners in tourism development $[9,22,29]$, functioning as valuable assets in tourism development promotion and ensuring the success of tourism destinations.

Destination tourism managers have to take into account the importance of involving residents in their tourism planning by trying to affect their perceptions of place attachment and quality of life. Residents have to be important players of tourism development. In a very rooted product, as olive oil is in Mediterranean countries and communities, it is essential to take into account the material and oral heritage of olive oil production-traditions, legends, lifestyles and so on. Residents have to be invited to share their knowledge about the olive oil culture with tourism planners. Planners should use that information to design authentic tourism experiences which reflect the idiosyncrasy of the place. This could be a way to enhance the senses of personal identification, place belonging and pride, and accordingly the residents' place attachment. Moreover, residents have to be conscious about the importance of tourism development in their quality of life. Tourism planners and residents have to bear in mind that infrastructure improvements for increasing tourism and the development of tourism activities, such as festivals, are not only for the enjoyment of visitors. Tourism development has to be implemented in accordance with residents' quality of life enhancement and the preservation of the rural heritage in a sustainable way. To reach these aims using a communication channel is required. Residents have to be aware of the project, its progress and achievements. The institutional local websites, local media or giving public talks could be good mechanisms to link residents to their tourism development.

Furthermore, the commercialization of local agrifood products have to take advantage of rural tourism development, as olive oil in this study. Local products can benefit from a new commercialization channel, which is the direct selling to tourists. Also the agrifood producers can profit from an improvement of the product brand image linked with the destination, more so when the product has a Designation of Origin, as in the case of Gata-Hurdes olive oil. A quality product brand linked to the territory can enhance the product competitiveness in the global market and the destination image.

The present study's limitation lies in its specific geographical context and tourism development setting of olive oil tourism. Thus, future research needs to replicate this study in other contexts to test the scope and magnitude of the above results, as well as to develop a deeper understanding of other relevant variables. This could improve plans for tourism destinations' development, guaranteeing their success by including the vital component of residents' support.

Acknowledgments: This work counts with the support of the European Regional Development Fund, European Union, and the Council of Economy and Infrastructure, Regional Government of Extremadura (Spain), in the context of the Project 'AOVETUR_EXTREM. A proposal for a model to the sustainable integral development of rural areas in Extremadura based on the binomial Extra Virgin Olive Oil and Tourism' (Ref. IB16104).

\section{JUNTA DE EXTREMADURA}

Consejería de Economia e Infraestructuras

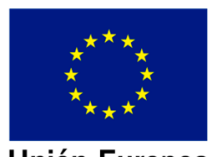

Unión Europea

Fondo Europeo de Desarrollo Regional Una manera de hacer Europa

Author Contributions: Ana María Campón-Cerro designed the study and wrote the paper, José Antonio Folgado-Fernández conducted the fieldwork, José Manuel Hernández-Mogollón assessed the analysis of the results and contributions and refined the paper.

Conflicts of Interest: The authors declare no conflict of interest. 


\section{References}

1. Gannon, A. Rural tourism as a factor in rural community economic development for economies in transition. Soc. Behav. Pers. 1994, 2, 51-60. [CrossRef]

2. Cánoves, G.; Herrera, L.; Villarino, M. Turismo rural en España: Paisajes y usurarios, nuevos usos y nuevas visiones. Cuad. Turismo 2005, 15, 63-76.

3. Yagüe, R.M. Rural tourism in Spain. Ann. Tour. Res. 2002, 29, 1101-1110. [CrossRef]

4. Alonso, A.D.; Northcote, J. The development of olive tourism in Western Australia: A case study of an emerging tourism industry. Int. J. Tour. Res. 2010, 12, 696-708. [CrossRef]

5. Cañero, P.M.; López-Guzmán, T.J.; Moral, S.; Orgaz, F. Análisis de la demanda del oleoturismo en Andalucía/Analysis of demand of olive tourism in Andalusia. Rev. Estud. Reg. 2015, 104, 133.

6. Andrés, J.L. Aportaciones básicas del turismo al desarrollo rural. Cuad. Turismo 2000, 6, 45-60.

7. Besteiro, B. El turismo rural en Galicia. Análisis de su evolución en la última década. Cuad. Turismo 2006, 17, 25-49.

8. García, J.L. El turismo rural como factor diversificador de rentas en la tradicional economía agraria. Estud. Turísticos 1996, 132, 45-60.

9. Gursoy, D.; Jurowski, C.; Uysal, M. Resident attitudes: A structural modeling approach. Ann. Tour. Res. 2002, 29, 79-105. [CrossRef]

10. Nunkoo, R.; So, K.K.F. Residents' support for tourism: Testing alternative structural models. J. Travel Res. 2015, 55, 847-861. [CrossRef]

11. Andereck, K.L.; Valentine, K.M.; Knopf, R.C.; Vogt, C.A. Residents' perceptions of community tourism impacts. Ann. Tour. Res. 2005, 32, 1056-1076. [CrossRef]

12. McGehee, N.G.; Andereck, K.L. Factors predicting rural residents' support of tourism. J. Travel Res. 2004, 43, 131-140. [CrossRef]

13. Chuang, S.T. Rural tourism: Perspectives from social exchange theory. Soc. Behav. Pers. 2010, 38, 1313-1322. [CrossRef]

14. Muresan, I.C.; Oroian, C.F.; Harun, R.; Arion, F.H.; Porutiu, A.; Chiciudean, G.O.; Todea, A.; Lile, R. Local residents' attitude toward sustainable rural tourism development. Sustainability 2016, 8. [CrossRef]

15. Marzo-Navarro, M.; Pedraja-Iglesias, M.; Vinzón, L. Sustainability indicators of rural tourism from the perspective of the residents. Tour. Geogr. 2015, 17, 586-602. [CrossRef]

16. Long, P.T.; Perdue, R.R.; Allen, L. Rural resident tourism perceptions and attitudes by community level of tourism. J. Travel Res. 1990, 28, 3-9. [CrossRef]

17. Woo, E.; Kim, H.; Uysal, M. Life satisfaction and support for tourism development. Ann. Tour. Res. 2015, 50, 84-97. [CrossRef]

18. Ward, C.; Berno, T. Beyond social exchange theory: Attitudes toward tourists. Ann. Tour. Res. 2011, 38, 1556-1569. [CrossRef]

19. Abdollahzadeh, G.; Sharifzadeh, A. Rural residents' perceptions toward tourism development: A study from Iran. Int. J. Tour. Res. 2014, 16, 126-136. [CrossRef]

20. Almeida-García, F.; Peláez-Fernández, M.Á.; Balbuena-Vázquez, A.; Cortés-Macias, R. Residents' perceptions of tourism development in Benalmádena (Spain). Tour. Manag. 2016, 54, 259-274. [CrossRef]

21. Nunkoo, R.; Gursoy, D. Residents' support for tourism: An identity perspective. Ann. Tour. Res. 2012, 39, 243-268. [CrossRef]

22. Nunkoo, R.; Ramkissoon, H. Developing a community support model for tourism. Ann. Tour. Res. 2011, 38, 964-988. [CrossRef]

23. Stylidis, D.; Biran, A.; Sit, J.; Szivas, E.M. Residents' support for tourism development: The role of residents' place image and perceived tourism impacts. Tour. Manag. 2014, 45, 260-274. [CrossRef]

24. Lee, T.H. Influence analysis of community resident support for sustainable tourism development. Tour. Manag. 2013, 34, 37-46. [CrossRef]

25. Nicholas, L.N.; Thapa, B.; Ko, Y.J. Residents' perspectives of a World Heritage Site: The Pitons Management Area, St. Lucia. Ann. Tour. Res. 2009, 36, 390-412. [CrossRef]

26. Deery, M.; Jago, L.; Fredline, L. Rethinking social impacts of tourism research: A new research agenda. Tour. Manag. 2012, 33, 64-73. [CrossRef] 
27. Kim, K.; Uysal, M.; Sirgy, M.J. How does tourism in a community impact the quality of life of community residents? Tour. Manag. 2013, 36, 527-540. [CrossRef]

28. Jeon, M.M.; Kang, M.M.; Desmarais, E. Residents' perceived quality of life in a cultural-heritage tourism destination. Appl. Res. Qual. Life 2016, 11, 105-123. [CrossRef]

29. Gursoy, D.; Rutherford, D.G. Host attitudes toward tourism: An improved structural model. Ann. Tour. Res. 2004, 31, 495-516. [CrossRef]

30. Tsai, S.P. Place attachment and tourism marketing: Investigating international tourists in Singapore. Int. J. Tour. Res. 2012, 14, 139-152. [CrossRef]

31. Kil, N.; Holland, S.M.; Stein, T.V.; Ko, Y.J. Place attachment as a mediator of the relationship between nature-based recreation benefits and future visit intentions. J. Sustain. Tour. 2012, 20, 603-626. [CrossRef]

32. Gursoy, D.; Kendall, K.W. Hosting mega events: Modeling locals' support. Ann. Tour. Res. 2006, 33, 603-623. [CrossRef]

33. Ko, D.W.; Stewart, W.P. A structural equation model of residents' attitudes for tourism development. Tour. Manag. 2002, 23, 521-530. [CrossRef]

34. Dyer, P.; Gursoy, D.; Sharma, B.; Carter, J. Structural modeling of resident perceptions of tourism and associated development on the Sunshine Coast, Australia. Tour. Manag. 2007, 28, 409-422. [CrossRef]

35. Jurowski, C.; Gursoy, D. Distance effects on residents' attitudes toward tourism. Ann. Tour. Res. 2004, 31, 296-312. [CrossRef]

36. Liang, Z.X.; Hui, T.K. Residents' quality of life and attitudes toward tourism development in China. Tour. Manag. 2016, 57, 56-67. [CrossRef]

37. Hair, J.F.; Ringle, C.M.; Sarstedt, M. PLS-SEM: Indeed a silver bullet. J. Mark. Theory Pract. 2011, 19, $139-151$. [CrossRef]

38. Ciavolino, E.; Nitti, M. Using the hybrid Two-Step estimation approach for the identification of second-order latent variable models. J. Appl. Stat. 2013, 40, 508-526. [CrossRef]

39. Wright, R.T.; Campbell, D.E.; Thatcher, J.B.; Roberts, N. Operationalizing multidimensional constructs in structural equation modeling: Recommendations for IS research. Commun. Assoc. Inf. Syst. 2012, 30, 367-412.

40. MacKenzie, S.B.; Podsakoff, P.M.; Jarvis, C.B. The problem of measurement model misspecification in behavioral and organizational research and some recommended solutions. J. Appl. Psychol. 2005, 90, 710-730. [CrossRef] [PubMed]

41. Barclay, D.; Higgins, C.; Thompson, R. The Partial Least Squares (PLS) approach to causal modelling: Personal computer adoption and use as an illustration. Technol. Stud. 1995, 2, 285-309.

42. Nunnally, J.C.; Bernstein, I. Psychometric Theory; McGraw-Hill: New York, NY, USA, 1994; ISBN 978-0070478497.

43. Falk, R.F.; Miller, N.B. A Primer for Soft Modeling; The University of Akron: Akron, OH, USA, 1992; ISBN 9780962262845 .

(C) 2017 by the authors. Licensee MDPI, Basel, Switzerland. This article is an open access article distributed under the terms and conditions of the Creative Commons Attribution (CC BY) license (http:/ / creativecommons.org/licenses/by/4.0/). 